\title{
A comparison of the effects of soya isoflavonoids and fish oil on cell proliferation, apoptosis and the expression of oestrogen receptors $\alpha$ and $\beta$ in the mammary gland and colon of the rat
}

\author{
Franziska Kramer ${ }^{1}$, Ian T. Johnson ${ }^{2}$, Joanne F. Doleman ${ }^{2}$ and Elizabeth K. Lund ${ }^{2} *$

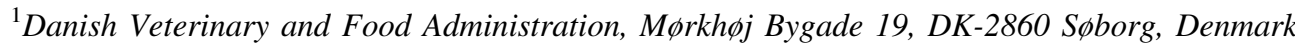 \\ ${ }^{2}$ Institute of Food Research, Colney, Norwich NR4 7UA, UK \\ (Received 11 April 2008 - Revised 20 October 2008 - Accepted 21 October 2008 - First published online 12 December 2008)
}

Isoflavonoids and fish oil may be protective against colorectal cancer, but the evidence in relation to breast cancer risk is ambiguous. In the present study, we have investigated the impact of soya-derived isoflavonoids and $n-3$ fatty acids from fish oil, both individually and in combination, on apoptosis, cell proliferation and oestrogen receptor (ER) expression in the colon and mammary gland of the rat. Female rats were fed diets high in $n$-3 fatty acids $(80 \mathrm{~g} / \mathrm{kg}$ diet) or soya protein $(765 \mathrm{mg} / \mathrm{kg}$ diet isoflavones) for 2 weeks, and then killed before the removal of the colon and mammary glands. Cell proliferation and apoptosis were quantified morphologically in whole crypts and terminal end buds. The expressions of $E R \alpha$ and $E R \beta$ were measured in colon tissue scrapes and the mammary gland. Fish oil significantly increased apoptosis and decreased mitosis in both tissues, an effect associated with a decrease in the expressions of $E R \alpha$ and $E R \beta$. Soya had no effect on apoptosis in either tissue, but reduced mitosis in the colon $(P<0.001)$ while increasing it in the mammary gland $(P=0.001)$. The changes in proliferation were associated with contrasting changes in the $E R$ expression such that fish oil significantly decreased both $E R \beta$ and $E R \alpha$, while soya increased $E R \alpha$ and decreased $E R \beta$. The results may provide a novel mechanism by which $n-3$ fatty acids could reduce cancer risk, but the interpretation of the results in relation to soya consumption and breast cancer risk requires further investigation.

n-3 Fatty acids: Isoflavones: Apoptosis: Mitosis: Oestrogen receptor

Epidemiological studies suggest that soya consumption is associated with a reduced risk of both breast and colorectal cancers $^{(1,2)}$. The active compounds in soya are generally suggested to be isoflavonoids, which are polyphenolic secondary metabolites with hormonal activity in mammals. However, there is some evidence that soya protein itself may contain bioactive components ${ }^{(3)}$. Both in vitro and in vivo studies of soya isoflavonoids have revealed their oestrogenic/antioestrogenic properties ${ }^{(4-7)}$. Oestrogen receptor (ER) $\alpha$ and ER $\beta$ are two major subtypes of the ER, both of which are the members of the nuclear receptor family ${ }^{(8)}$. Isoflavonoids can bind to ER and activate them, but with a higher binding affinity to $\mathrm{ER} \beta$ when compared with $\mathrm{ER} \alpha^{(8)}$. The hormonal properties of the isoflavonoids are believed to be the main reason for their protective effects in relation to mammary cancer, though other mechanisms may also be important ${ }^{(9)}$.

While the importance of oestrogen signalling in mammary gland cancer is widely accepted, the involvement of hormones in the development of colorectal cancer is less well documented. Nevertheless, colon cancer is more common in men than women, and male rats exposed to chemical carcinogens are significantly more likely to develop tumours than their female counterparts ${ }^{(10)}$. Additionally, the use of hormone replacement therapy has been shown to reduce the risk of colorectal cancer but increase the risk of breast cancer ${ }^{(11)}$. In healthy mammary tissue, $\mathrm{ER} \alpha$ is involved in the growth and development of the gland and is regulated by oestrogens ${ }^{(12)}$. However, in hormone-dependent mammary cancer, ER $\alpha$ has been reported to be over-expressed in precancerous tissue, while ER $\beta$ is apparently down-regulated in both preneoplastic tissue and tumour ${ }^{(13)}$, as a consequence of cytosine-phosphoguanine $(\mathrm{CpG})$ island hypermethylation ${ }^{(14)}$. In the human colon, $E R \beta$ (ESR2) gene expression is dominant over that of $E R \alpha(E S R 1)$ in apparently normal mucosa taken from patients with tumours, while in the tumour and cell lines, the expressions of both $E R \alpha$ and $E R \beta$ are reported to be lower ${ }^{(15)}$. The reduction in the $E R \beta$ expression associated with tumour development is reflected by changes in protein levels ${ }^{(16)}$. Studies on associations between common genetic variants of $E R \alpha$ and $E R \beta$ and the risk of colorectal cancer in men and women suggest that $\mathrm{ER} \beta$ plays an important role in the aetiology of the disease ${ }^{(17)}$.

Epidemiological evidence also provides support for a protective effect of fish consumption in relation to colorectal cancer $^{(18)}$, and this is generally ascribed to the high $n-3$ fatty acid content of oil-rich fish. This hypothesis is supported by

Abbreviations: ER, oestrogen receptor; GAPDH, glyceraldehyde-3-phosphate dehydrogenase housekeeping gene; RXR, retinoic acid x receptor; TEB, terminal end bud. * Corresponding author: Elizabeth K. Lund, fax + 441603 507723, email liz.lund@bbsrc.ac.uk 
the evidence from animal studies using a range of models of colorectal cancer ${ }^{(19-21)}$, and by human intervention studies where cell proliferation and apoptosis are used as markers of risk $^{(22,23)}$. There are many potential mechanisms of action by which $n-3$ fatty acids may modulate tumour risk in the colon $^{(24)}$, including signalling through the PPAR nuclear receptor family, which act as transcription factors ${ }^{(25)}$, reduced cell proliferation and increased apoptosis, and modulation of the redox state ${ }^{(26,27)}$. The epidemiological evidence for a protective effect of fish and fish oils in relation to mammary cancer development is less convincing ${ }^{(28,29)}$, although some studies are supportive ${ }^{(30,31)}$. Similarly, studies using different animal models provide conflicting evidence; Karmali et al. ${ }^{(32)}$ reported no protective effect of $n-3$ fatty acids in rats exposed to the carcinogen 7,12-dimethylbenz $[a]$ anthracene, and in the same model ${ }^{(33)}$ showed an increase in tumorigenesis with an increasing $n-3: n-6$ ratio. However, in a rat model incorporating a mammary adenocarcinoma transplant, $n-3$ fatty acids have been shown to be protective ${ }^{(34)}$.

The aim of the present study was to investigate the effect of exposure to isoflavonoid-rich soya protein and $n-3$ fatty acids on the expression of $E R \alpha$ and $E R \beta$, cell proliferation and apoptosis in both the mammary gland and the colon of the rat.

\section{Materials and methods \\ Animals and exposure protocols}

Female Sprague-Dawley rats, aged 8 weeks, were purchased from Charles River (Margate, Kent, UK). The animals were kept in a $12 \mathrm{~h}$ light and $12 \mathrm{~h}$ dark cycle at an average temperature of $22^{\circ} \mathrm{C}$ and a humidity of $55 \%$. The animals were fed $\mathrm{ad}$ libitum on a semi-synthetic diet (Table 1, control diet). At arrival, the animals were weighed, randomised and placed in pairs in cages. All research were carried out according to the UK Home Office Regulations and approved by a local research ethics committee.

Table 1. The composition of the semi-synthetic diets used in experiments 1 and 2 (in experiment 2, only the first three diets were used)

\begin{tabular}{|c|c|c|c|c|}
\hline & Control & Fish oil & Soya & Fish oil + soya \\
\hline Starch $(\mathrm{g} / \mathrm{kg})$ & 280 & 280 & 280 & 280 \\
\hline Sucrose $(\mathrm{g} / \mathrm{kg})$ & 380 & 380 & 380 & 380 \\
\hline Casein $(\mathrm{g} / \mathrm{kg})$ & 200 & 200 & 200 & 200 \\
\hline Soya protein $(\mathrm{g} / \mathrm{kg})$ & - & - & 5 & 5 \\
\hline Maize oil $(\mathrm{g} / \mathrm{kg})$ & 80 & - & 80 & - \\
\hline SFA $(g / k g)^{*}$ & $13 \cdot 0$ & $32 \cdot 8$ & $13 \cdot 0$ & $32 \cdot 8$ \\
\hline MUFA $(\mathrm{g} / \mathrm{kg})^{\star}$ & $25 \cdot 8$ & $18 \cdot 5$ & $25 \cdot 8$ & 18.5 \\
\hline$n-6$ PUFA $(\mathrm{g} / \mathrm{kg})^{*}$ & 40.4 & 2.6 & 40.4 & $2 \cdot 6$ \\
\hline$n-3$ PUFA $(\mathrm{g} / \mathrm{kg})^{*}$ & 0.8 & $26 \cdot 1$ & 0.9 & $26 \cdot 1$ \\
\hline Fish oil $(\mathrm{g} / \mathrm{kg})$ & - & 80 & - & 80 \\
\hline SFA $(\mathrm{g} / \mathrm{kg})^{\star}$ & $13 \cdot 0$ & $32 \cdot 8$ & 13.0 & $32 \cdot 8$ \\
\hline MUFA $(\mathrm{g} / \mathrm{kg})^{\star}$ & $25 \cdot 8$ & 18.5 & $25 \cdot 8$ & $18 \cdot 5$ \\
\hline$n-6$ PUFA $(\mathrm{g} / \mathrm{kg})^{*}$ & 40.4 & $2 \cdot 6$ & $40 \cdot 4$ & $2 \cdot 6$ \\
\hline$n-3$ PUFA $(\mathrm{g} / \mathrm{kg})^{*}$ & 0.8 & $26 \cdot 1$ & 0.9 & $26 \cdot 1$ \\
\hline Isoflavones $(\mathrm{mg}) \dagger$ & - & - & 765 & 765 \\
\hline Mineral mix $\ddagger$ & 40 & 40 & 40 & 40 \\
\hline Vitamin mix $\ddagger$ & 20 & 20 & 20 & 20 \\
\hline
\end{tabular}

* Calculated fatty acid composition.

† Detailed composition is shown in Table 2.

† Mineral and vitamin mix are as described previously ${ }^{(39)}$
Experiment 1. This initial experiment was performed in order to assess the impact of fish oil and isoflavonoid-rich protein on mitosis and apoptosis, as well as to investigate whether there was any interaction between the two ingredients under investigation. After 1 week of acclimatisation to the control semi-synthetic diet, the oestrous cycle was checked daily by vaginal flushing. After a period of two oestrous cycles, the animals were exposed to one of four diets ( $n$ 12): control diet (as mentioned previously); soya diet ( $5 \mathrm{~g} / \mathrm{kg}$ diet of isoflavonoid-enriched protein, Soylife ${ }^{\mathrm{TM}}$, Giessen, The Netherlands (Table 2), added to the control diet mix to give a final isoflavonoid concentration of $765 \mathrm{mg} / \mathrm{kg}$ diet); fish-oil diet (maize oil replaced by menhaden oil; Sigma, Poole, Dorset, UK); a diet containing both fish oil and isoflavonoid-enriched protein (Table 1). The replacement of maize oil by fish oil resulted in a reduction in $n-6$ fatty acids from 50 to $4 \%$ of total fatty acids and an increase in $n$ - 3 fatty acids from 2 to $30 \%$, such that the ratio of $n-6: n-3$ fatty acids changed from 25:1 to 1:10. The animals received diet and water ad libitum, and were weighed daily throughout the study period. The animals were exposed to the diet for a period of three oestrous cycles (14-15d), starting and finishing during oestrous. At the end of the dietary period, the animals were killed by cervical dislocation following anaesthesia with sodium barbital. Blood samples $(5 \mathrm{ml})$ were collected from the inferior vena cava into heparinised tubes, and the plasma frozen at $-80^{\circ} \mathrm{C}$ until analysis for circulating levels of daidzein, glycitein, genistein and equol, as described previously ${ }^{(35)}$. (For this analysis, two samples were pooled together, to provide sufficient volume, from a randomly selected subset of ten animals per group so that there are five animals in each group.) The abdominal and thoracic mammary glands were dissected and fixed in ethanol-acetic acid (75:25). Colon was removed, flushed with PBS ( $\mathrm{pH} 7.4)$, measured and weighed before the fixation of the distal third in ethanol-acetic acid $(75: 25, \mathrm{v} / \mathrm{v})$, and liver and uterine weight were recorded.

Experiment 2. A second experiment was conducted to assess the impact of the two dietary modifications on oestrogen expression in the colon and mammary gland. Following 1 week of acclimatisation, the oestrous cycle was checked daily for a period of $5 \mathrm{~d}$ by vaginal flushing. Thereafter, the animals were exposed to $0.5 \%$ Soylife $^{\mathrm{TM}}$ isoflavones in the diet (Table 1) or menhaden oil $(80 \mathrm{~g} / \mathrm{kg})$. After 2 weeks of exposure (equivalent to three oestrus cycles), the animals were killed by cervical dislocation following anaesthesia with sodium barbital. Before the animals were killed, the

Table 2. Concentration of isoflavones in Soylife ${ }^{\mathrm{TM}}$

\begin{tabular}{lc}
\hline Compound & Concentration $(\mathrm{mg} / \mathrm{g})$ \\
\hline Glycitein & 31.29 \\
Malonylglycitein & $<0.05$ \\
Acetylglycitein & 13.76 \\
Glycitein & 4.30 \\
Daidzein & 34.99 \\
Malonyldaidzein & $<0.05$ \\
Acetyldaidzein & 39.13 \\
Daidzein & 2.04 \\
Genistein & 16.43 \\
Malonylgenistein & 0.15 \\
Acetylgenistein & 10.18 \\
Genistein & 0.78 \\
Total isoflavones & 153.0
\end{tabular}


stage of oestrous was determined. The abdominal mammary gland was removed and immediately after excision placed in RNAlater $^{\mathrm{TM}}$ (Ambion, Austin, TX, USA). Colon was removed, flushed with RNAlater ${ }^{\mathrm{TM}}$, scraped and the scrape placed in RNAlater ${ }^{\mathrm{TM}}$. Tissue in RNAlater ${ }^{\mathrm{TM}}$ was left at $4^{\circ} \mathrm{C}$ overnight and stored at $-20^{\circ} \mathrm{C}$ for later analysis. Each group consisted of thirty animals.

\section{Mitosis and apoptosis}

Mitosis and apoptosis were assessed by morphological criteria. Briefly, tissues were fixed in ethanol-acetic acid (75:25, v/v) and stained with Feulgen's reagent, as described by Latham et al. ${ }^{(27)}$. Colonic crypts and mammary tissue were dissected under a low-power binocular microscope and, afterwards, the number of apoptotic and mitotic cells per crypt or terminal end bud (TEB), the most proliferative structures in the mammary gland, was counted under a light microscope (magnification $400 \times$ ). Ten structures per animal per tissue were analysed.

\section{Oestrogen receptor expression}

ER expression was assessed by fully quantitative real-time RT-PCR using TaqMan. The probes and primers were designed using Primer Express Software version 1.5 (ABI Applied Biosystems, Warrington, UK) and HPLC-purified primers and probes were purchased from Sigma-Genosys Ltd (Haverhill, UK).

\section{Oestrogen receptor $\alpha$ gene}

Probe: AGA TGC TCC ATG CCT TTG TTA CTC ATG TG Forward primer: $5^{\prime}$-GGCACGACATTCTTGCATTTC Reverse primer: $5^{\prime}$-CTGGCCCAGCTCCTCCTC

\section{Oestrogen receptor $\beta$ gene}

\author{
Probe: AAC AGG CTG AGC TCC ACA AAG CC \\ Forward primer: CCCACCATTAGCACCTCCAT \\ Reverse primer: 5'-GATGATGTCCCTCACTAAGCTGG
}

Glyceraldehyde-3-phosphate dehydrogenase housekeeping gene

\section{Probe: CATGACCACAGTCCATGCCATCACT \\ Forward primer: 5'-TGACAACTTTGGCATCGTGG \\ Reverse primer: 5'-TGATGTTCTGGGCTGCCC}

TaqMan standard curves were generated using recombinant plasmids of the genes of interest. Briefly, $2 \mu \mathrm{g}$ total RNA extracted from the proximal small intestine was reverse transcribed using an oligo-dT primer and the Omniscript RT kit (Qiagen, Valencia, CA, USA). Five microlitres each of cDNA were used as a template for PCR to amplify ER $\alpha$, ER $\beta$ or glyceraldehyde-3-phosphate dehydrogenase housekeeping gene $(\mathrm{GAPDH})$. PCR products were run on a $2 \%$ agarose, $1 \times$ tris acetate ethylenediaminetetraacetic acid (TAE) gel and purified from the gel using a QIAquick gel extraction kit (Qiagen). Each PCR amplicon was cloned into a pCR4-TOPO vector using the TOPO TA cloning kit for sequencing (Invitrogen, Carlsbad, CA, USA) before transformation into Escherichia coli TOP10 competent cells. Single colonies were picked, purified plasmid stocks were prepared using a Qiagen plasmid mini kit and their sequence was verified. The concentration of the primers and probes for TaqMan was optimised and found to be $300 \mathrm{nM}$ forward and reverse primers for both GAPDH and ER $\alpha$ and $900 \mathrm{~nm}$ for ER $\beta$. Probe concentrations were optimised to 200,250 and $100 \mathrm{~nm}$ for $\mathrm{ER} \beta$, GAPDH and $\mathrm{ER} \alpha$, respectively.

RNA from samples was extracted using an RNeasy ${ }^{\circledR}$ kit (Qiagen). RNA quantity and quality was analysed using the RNA 6000 Nano assay kit using the Agilent 2100 Bioanalyzer. cDNA was synthesised from 1 to $2 \mu \mathrm{g}$ RNA depending on the total amount extracted using the Omniscript ${ }^{\mathrm{TM}}$ RT kit (Qiagen). GAPDH was measured as a housekeeping gene using TaqMan ${ }^{\circledR}$ Rodent GAPDH control reagents (Applied Biosystems, Foster City, CA, USA), but, ultimately, this was not used for normalisation as recommended by Bustin ${ }^{(36)}$

PCR were performed on the ABI TaqMan 7700 sequence detector (ABI Applied Biosystems). Reaction volumes $(25 \mu \mathrm{l})$ were used containing $3 \mu \mathrm{l}$ cDNA, probe primer, $12.5 \mu \mathrm{l}$ TaqMan Universal PCR Master Mix (ABI Applied Biosystems) and double-labelled water in a $25 \mu$ l reaction volume. All samples were analysed in triplicate and all data were related to the original total RNA content. Hall \& McDonnell ${ }^{(37)}$ have shown using transfection studies in cell lines that high levels of ER $\beta$ desensitise the cell to oestrogen and down-regulate ER $\alpha$ expression, such that it is not the absolute levels of the expressions of ER $\alpha$ and ER $\beta$ that are important but the ratio of $\mathrm{ER} \alpha$ to $\mathrm{ER} \beta$ that determines cellular responses to both agonists and antagonists of either ER. We have therefore expressed the present results as the $E R \alpha: E R \beta$ ratio for each tissue sample.

\section{Statistical analysis}

Statistical analysis was performed using the Minitab statistics package (version 14). The one-way ANOVA was used and the difference between groups was assessed using Tukey's post hoc test. The two-way ANOVA and assessment of interactions between treatment groups were performed using the General Linear Model tool within the Minitab.

\section{Results}

Neither total body weight nor the weight of colon, liver and uterus relative to body weight were affected by diet. Neither fish-oil nor soya protein diets affected the length of the oestrous cycle $(4-5 \mathrm{~d})$.

\section{Apoptosis and mitosis}

Exposure to both soya extract and fish oil resulted in a reduction in the region of $35 \%(P=0.004$ and 0.001 , respectively $)$ in the number of mitotic cells per colonic crypt (Fig. 1(a)). An interaction between fish oil and soya protein was identified $(P=0.003)$, although the mean values for all three treatment groups were similar. By contrast, dietary soya protein resulted in a $30 \%$ increase $(P<0.001)$ in the number of mitotic cells per TEB (Fig. 2(a)), whereas fish oil led to a $33 \%$ decrease 
(a)

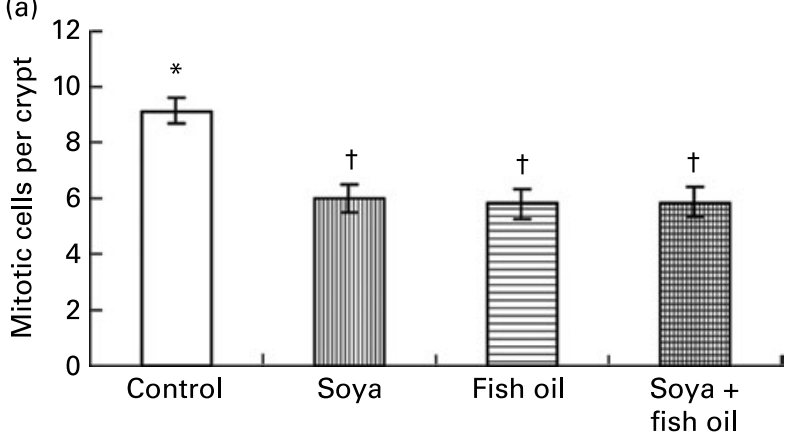

(b)

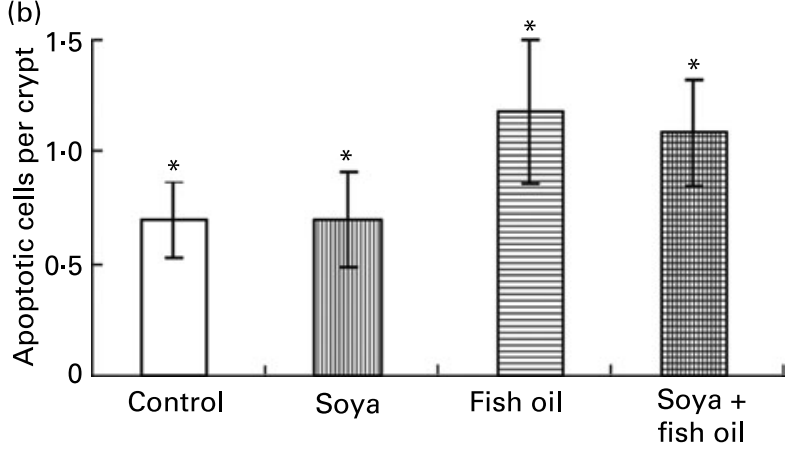

Fig. 1. A comparison between the effects of feeding rats a diet high in phytooestrogen-enriched soya protein and that of adding fish oil to the diet on colon crypt cell (a) mitosis and (b) apoptosis. The values represent the mean ( $n$ 12) and standard deviation with a significant difference between groups indicated by symbols. The values not sharing the same symbol are significantly different $(P<0.05)$. The results from the two-way ANOVA using the general linear model are as follows: soya protein, (a) $P=0.004$ and (b) $P=$ NS; fish oil, (a) $P=0.001$ and (b) $P=0.05$; fish $\times$ soya interaction, (a) $P=0.003$ and (b) $P=$ NS. Ten crypts were analysed per animal.

$(P<0.001)$, and the effect of combining the two treatments was additive such that no effect was detectable.

While soya exposure alone had no effect on apoptosis in either tissue, fish oil induced apoptosis in both the colon $(P=0.05)$ and mammary gland $(P=0.05$; Figs. $1(\mathrm{~b})$ and $2(\mathrm{~b}))$. Interestingly, statistical analysis showed a highly significant interaction $(P=0.003)$ between fish-oil and soya diets in relation to apoptosis in the mammary gland such that soya protein did enhance apoptosis in the presence of fish oil. This is in contrast to the results in the colon where there was no interaction between soya and fish oil in relation to apoptosis.

\section{Plasma isoflavonol concentrations}

Isoflavonols, daidzein, glycitein, genistein and equol were only detectable in the animals fed the isoflavonoid-enriched soya protein. There were no significant differences in the concentrations of each compound between the animals fed soya with maize oil and those fed soya with fish oil (Table 3 ).

\section{Oestrogen receptor expression}

Analysis of the ER expression by RT-PCR revealed that in colonic mucosa, ER $\alpha$ was expressed at more than three times the level of $E R \beta$ (Table 4). Both soya protein and fish oil reduced $E R \alpha$ expression and induced $E R \beta$ expression, leading to significant reductions in the ratio of $E R \alpha$ to $E R \beta$ (Fig. 3(a)). In the
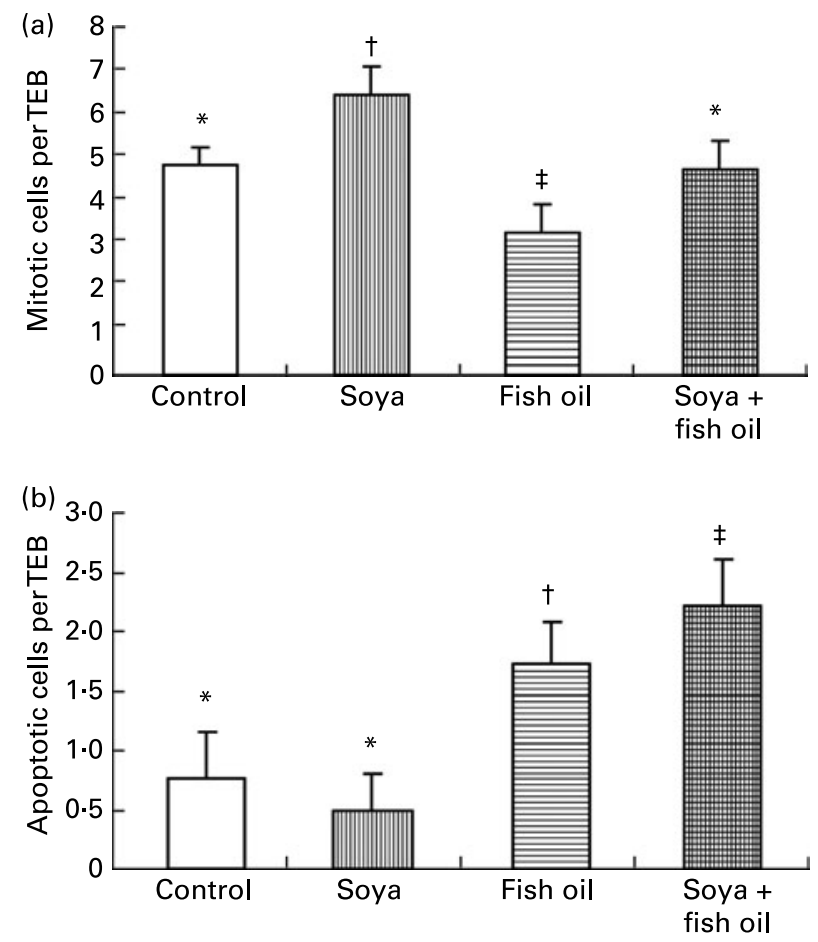

Fig. 2. A comparison between the effects of feeding rats a diet high in phytooestrogen-enriched soya protein and that of adding fish oil to the diet on mammary gland terminal end bud (TEB) (a) mitosis and (b) apoptosis. The bars represent the mean and standard deviation for each group ( $n$ 12) with a significant difference between groups indicated by symbols. The values not sharing the same symbol are significantly different $(P<0.05)$. The results from the two-way ANOVA using the general linear model are as follows: soya protein, (a) $P<0.001$ and (b) $P=N S$; fish oil, (a) $P<0.001$ and (b) $P<0.001$; fish $\times$ soya interaction, (a) $P=$ NS and (b) $P=0.003$. Ten TEB were analysed per animal.

colon, the impact of soya at the dose used in the present study was greater than that of fish oil for both genes studied.

By contrast, $E R \beta$ is more highly expressed in the rat mammary gland than $E R \alpha$ (Table 4). After exposure to soya or fish oil, ER $\alpha$ expression increased relative to controls, but soya induced a very marked decrease in $E R \beta$. Fish-oil exposure led to a small increase in the $E R \beta$ expression. Thus, the dominant effect of diet in relation to ER expression in the mammary gland was a reduction in the gene for ER $\beta$ by soya protein and a highly significant increase in the $E R \alpha: E R \beta$ ratio (Fig. 3(b)). Diet had no significant effect on the expression of the housekeeping gene GAPDH in either

Table 3. Plasma isoflavonoid concentrations in rats fed an isoflavonoidrich diet

(Mean values with standard deviation of five analyses obtained from ten samples, each containing a pooled sample from two rats)

\begin{tabular}{lllllr}
\hline & \multicolumn{2}{c}{$\begin{array}{c}\text { Soya diet with } \\
\text { maize oil }\end{array}$} & & \multicolumn{2}{c}{$\begin{array}{c}\text { Soya diet with } \\
\text { fish oil }\end{array}$} \\
\cline { 2 - 3 } \cline { 5 - 6 } & Mean & SD & & Mean & SD \\
\hline Daidzein $(\mu \mathrm{g} / \mathrm{ml})$ & 0.36 & 0.08 & & 0.62 & 0.41 \\
Glycitein $(\mu \mathrm{g} / \mathrm{ml})$ & 0.17 & 0.05 & & 0.26 & 0.17 \\
Genistein $(\mu \mathrm{g} / \mathrm{ml})$ & 0.80 & 0.26 & & 1.07 & 0.71 \\
Equol $(\mu \mathrm{g} / \mathrm{ml})$ & 2.89 & 1.87 & & 4.78 & 2.18 \\
\hline
\end{tabular}


Table 4. $E R \alpha$ and $E R \beta$ expressions in mammary gland and colon shown in copies/ug RNA

(Mean values with their standard deviations)

\begin{tabular}{|c|c|c|c|c|c|c|c|c|c|}
\hline & \multicolumn{3}{|c|}{ Control } & \multicolumn{3}{|c|}{ Soya } & \multicolumn{3}{|c|}{ Fish oil } \\
\hline & $n$ & Mean & SD & $n$ & Mean & SD & $n$ & Mean & SD \\
\hline \multicolumn{10}{|l|}{ Colon } \\
\hline$E R \alpha$ & 31 & $3.88 \times 10^{6 a}$ & $1.00 \times 10^{6}$ & 22 & $1.07 \times 10^{6 c}$ & $0.29 \times 10^{6}$ & 22 & $2.39 \times 10^{6 b}$ & $0.75 \times 10^{6}$ \\
\hline$E R \beta$ & 20 & $1.25 \times 10^{6 a}$ & $0.28 \times 10^{6}$ & 18 & $3.30 \times 10^{6 b}$ & $0.78 \times 10^{6}$ & 16 & $3.03 \times 10^{6 b}$ & $0.92 \times 10^{6}$ \\
\hline \multicolumn{10}{|c|}{ Mammary gland } \\
\hline$E R \alpha$ & 21 & $0.37 \times 10^{8 a}$ & $0.05 \times 10^{8}$ & 19 & $1.65 \times 10^{8 b}$ & $0.63 \times 10^{8}$ & 17 & $2.04 \times 10^{8 c}$ & $0.57 \times 10^{8}$ \\
\hline$E R \beta$ & 18 & $82.8 \times 10^{8 a}$ & $19.3 \times 10^{8}$ & 15 & $4.41 \times 10^{8 b}$ & $0.60 \times 10^{8}$ & 15 & $115.5 \times 10^{8 c}$ & $20.4 \times 10^{8}$ \\
\hline
\end{tabular}

a,b,c Mean values with unlike superscript letters within any one tissue and for each gene are significantly different $(P<0.01)$.

tissue, but the GAPDH data were not used to normalise ER results, instead we chose to use the $E R \alpha: E R \beta$ ratio for the reasons described previously.

\section{Discussion}

The importance of understanding the effects of multiple components of the diet on target tissues, rather than focusing
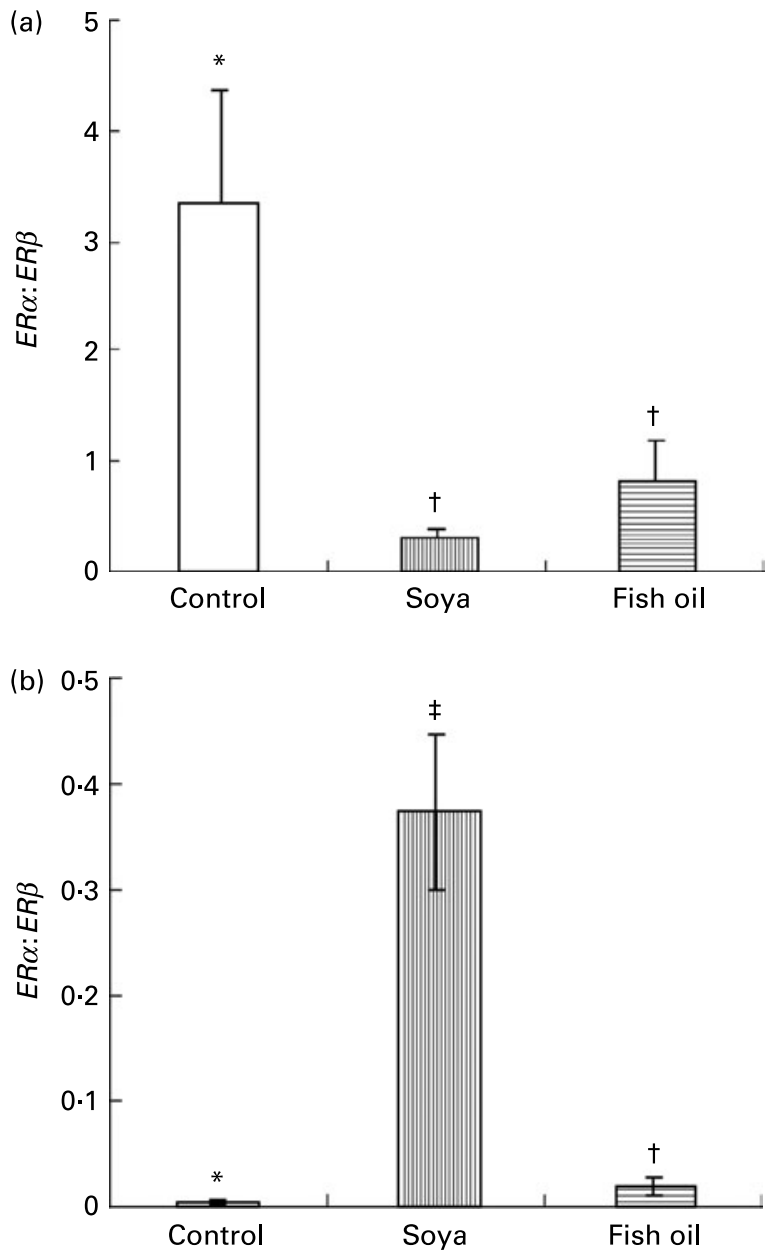

Fig. 3. The $E R \alpha: E R \beta$ gene expression ratio in response to feeding phytooestrogen-enriched soya protein or fish oil in (a) colonic or (b) mammary gland tissue. The error bars represent the standard deviation and the significant difference is indicated by symbols. The values not sharing the same symbol are significantly different $(P<0.05)$. on the effects of single nutrients on one tissue or organ, is now becoming recognised ${ }^{(38)}$. In the present study, we have chosen to approach this problem by examining the interactions between two dietary components, soya phyto-oestrogens and $n-3$ fatty acids, which are often consumed together in traditional Asian diets, and have been proposed as protective factors against breast and colorectal cancers. We have particularly chosen to focus on their effects on mitosis, apoptosis and ER expression, as there is evidence that this receptor plays a role in the cancers of both sites ${ }^{(15,39)}$. The doses used were such that no direct hormonal effects were observed in the animals, as assessed by uterine weight and changes in the oestrous cycle length over the period of the study.

Replacement of maize oil by fish oil in the diet reduced cell proliferation and induced apoptosis in both the colonic crypts and mammary gland TEB. For the colon, similar results have been reported previously by both ourselves ${ }^{(26,27,40)}$ and other groups ${ }^{(41)}$. There are many potential mechanisms by which the $n-3$ fatty acids found in fish oil might modify these parameters $^{(24)}$. No interactions between $n-3$ fatty acid intake and oestrogen metabolism have been reported previously, but it is entirely plausible that our observed reduction in the $E R \alpha$ expression may provide at least a partial explanation for the reduced cell proliferation observed, as it has previously been reported that ovariectomised mice have a reduced crypt length ${ }^{(42)}$. However, the importance of $E R \alpha$ gene expression in the human colon is doubtful, as the expression of the protein $(\mathrm{ER} \alpha)$ is very low, despite the high levels of gene expression, in both morphologically normal and tumour tissue from cancer patients ${ }^{(15,16)}$. ER $\beta$ is expressed in the 'normal' colon, and ER $\beta$ knock-out mice are reported to have cell proliferation rates 1.6-fold higher than that in wild-type mice with less well-differentiated cells on the luminal surface ${ }^{(43)}$. Thus, an increased expression of ER $\beta$ would be predicted to reduce cell proliferation, as observed in the present study. Interestingly, a reduced expression of ER $\beta$ is reported during tumorigenesis ${ }^{(15)}$. The observation that both soya protein and fish oil were able to up-regulate $E R \beta$ expression might therefore be considered consistent with the epidemiological evidence that both these dietary constituents are protective in relation to colorectal cancer ${ }^{(1,18)}$.

Although both soya protein and fish oil decreased cell proliferation, only fish oil was able to induce apoptosis. Over-expression of ER $\beta$ has been reported to increase apoptosis in colorectal cell lines ${ }^{(44)}$, and the lack of ER $\beta$ reduces apopto$\operatorname{sis}^{(42)}$, but this does not explain the differential effects of the two dietary components in the present study, even when the 
$E R \alpha: E R \beta$ ratio is considered. It is therefore likely that induction of apoptosis by fish oil does not involve signalling via the oestrogen response element, but, instead, probably acts through the modulation of the redox state ${ }^{(27)}$ or via PPAR/retinoic acid $x$ receptor (RXR) signalling pathways ${ }^{(24)}$. Further light might be shed on the interpretation of these data when we consider that the expression of ER $\beta$ protein is the highest in terminally differentiated colonocytes, whereas ER $\alpha$ protein is found in the sub$\operatorname{mucosa}^{(15,45,46)}$. The present results contrast with those recently published by Bises et al. ${ }^{(47)}$, who reported that the replacement of casein by soya protein in the diet of female mice led to an increase in the ER $\alpha$ expression in the proximal colon. A major difference between their study and the present study is that we added relatively little soya protein to the diet, rather than replacing casein by soya protein, and so the effects we have observed are more likely to be associated with soya phyto-oestrogens than any bioactive protein. Alternative explanations might include species difference, length of dietary intervention or the (unstated) phyto-oestrogen content of the soya protein. However, it is of interest that replacing casein in the diet by soya protein isolates low in isoflavonoids $(32 \mathrm{mg} / \mathrm{kg} \mathrm{diet})$ can modify protein expression of the nuclear receptor retinoic acid receptor $\beta$ in the liver but not in other tissues or isoforms ${ }^{(3)}$.

In the mammary gland, $E R \beta$ was the predominant gene, an observation consistent with the fact that ER $\beta$ is the main ER in the rodent mammary gland ${ }^{(48)}$. In contrast to the situation in the colon, fish oil and soya protein had opposing effects on cell proliferation in the mammary tissue, in that while soya protein increased mitosis in the TEB, the site of the highest proliferation and risk of tumour development ${ }^{(49)}$, fish oil reduced it. These opposing effects of the two dietary components on TEB mitosis are reflected in the observed opposite responses in the $E R \beta$ expression, with soya down-regulating the expression by a factor of approximately 20, while fish oil up-regulated the $E R \beta$ expression. They are also consistent with the opposing effects of hormone replacement therapy in relation to colon and breast cancers ${ }^{(17,50)}$.

The observed changes in the expression of $E R \beta$ in response to soya phyto-oestrogens in the diet are inconsistent with the results of previous cell culture studies using genistein, where the expressions of different $E R \beta$ isoforms were increased rather than being decreased ${ }^{(51)}$. However, in the colon, ER $\beta$ was increased in animals exposed to soya phyto-oestrogens. Earlier studies comparing the effects of coumestrol, genistein and daidzein on the ER $\alpha$ expression in breast cancer cell lines reported a down-regulation of the expression by coumestrol but not by either genistein or daidzein ${ }^{(52)}$; again, a different result from that reported in the present in vivo study. These differences may reflect contrasting effects in responses between tumour and normal cells, but the formation of equol in vivo is also likely to be an important factor. The doses to which cells are actually exposed to in vivo compared with those added to cell culture media and species differences will also have an impact.

It is far from clear how fish oil might modify ER expression. However, it is known that PUFA are agonists for PPAR and RXR, with the $n-3$ fatty acids preferentially binding $\mathrm{RXR}^{(53)}$. Recent studies have shown that PPAR $\alpha$ expression regulates $\mathrm{ER} \alpha$ expression ${ }^{(54)}$, and PPAR/RXR heterodimers have been shown to bind the oestrogen response element in the breast cancer cell line $\mathrm{MCF}-7^{(55)}$. Thus, $n-3$ fatty acids might modify ER expression via PPAR/RXR in both breast and colorectal tissues.

As we observed in the colon, apoptosis was only induced by fish oil and not by soya protein in the TEB, an effect that did not appear to be associated with the changes in either the $E R \alpha$ or $E R \beta$ expression. The results of the present study are consistent with the conclusions of Maggiolini et al. ${ }^{(56)}$ that the proliferative response to phyto-oestrogens is ER mediated, but not the cytotoxic effects seen at high doses. In contrast to the present results, Dave et al. ${ }^{(57)}$ reported an increase in apoptosis measured immunohistochemically in the TEB of rats fed genistein $(250 \mathrm{mg}$ aglycone $/ \mathrm{kg}$ diet $)$ or soya protein (216 mg genistein/160 mg daidzein) for approximately 4 weeks from weaning. The genistein levels were therefore considerably higher than those in the present study, and, additionally, the authors do not clarify in what proportion the isoflavones in the soya protein were in the aglycone form, which may also provide a partial explanation as to the difference in the results. They report no effect of soya on cell proliferation, but this was measured using proliferating cell nuclear antibody that detects cells in G2/M and can provide misleading results ${ }^{(58)}$.

The present data would suggest that the proliferative effect may be mediated by a down-regulation of $E R \beta$ rather than an increased expression of $E R \alpha$, as the expression of the latter was up-regulated in the mammary gland by both soya protein and fish oil, yet opposing effects of the two diets were seen in relation to proliferation. Fig. 3 shows that the $E R \alpha: E R \beta$ ratio is increased 80 -fold following the consumption of soya protein, which, if this is reflected at the level of protein expression, would mean a much increased sensitivity to circulating oestrogens and perhaps an increase in cell proliferation, which would be consistent with the present observations (Fig. 2). This large increase in the ratio was not observed in rats fed diets high in fish oil. Although dietary soya protein alone had no effect on apoptosis, there was a further increase in apoptosis when fish oil was present in the diet (Fig. 2(b)). The data on the ER expression in the present study do not offer any obvious explanation for this observation, suggesting an effect not mediated through the ER expression.

The interpretation of the present results in relation to mammary cancer risk is more complex than that for colorectal cancer. For example, following soya protein consumption, $\mathrm{ER} \alpha$ would be predicted to be over-expressed, which might be beneficial during mammary gland development but harmful in relation to tumour development. However, tamoxifen, the chemotherapeutic drug used in breast cancer treatment, which acts as an oestrogen antagonist and binds preferentially to $\mathrm{ER} \alpha$, might, from the present results, be more effective following the consumption of soya protein. ER $\alpha$-negative mammary gland tumours are refractive to tamoxifen treatment. Interestingly, EPA, one of the $n-3$ fatty acids present in fish oil, has previously been shown to restore tamoxifen sensitivity in breast cancer cells ${ }^{(59)}$, while flaxseed, high in both phyto-oestrogens and $n-3$ fatty acids, enhances the antiproliferative effects of tamoxifen in ER + cell lines. Furthermore, an increased expression of wild-type ER $\beta$ has been linked to a poor prognosis in relation to breast cancer, so the reduction in ER $\beta$ by the addition of soya phyto-oestrogens to the diet might also be predicted to be protective ${ }^{(60)}$. 
Breast cancer cells express not only ER but also progesterone and androgen receptors, through which soya isoflavones may also act ${ }^{(61,62)}$, and which are known to be involved in tamoxifen sensitivity ${ }^{(63)}$. Fish oil, like soya protein, increases the $E R \alpha: E R \beta$ ratio in the mammary gland, but only to a very small extent such that it is unlikely to be of concern in relation to cancer risk or chemotherapy.

We conclude that modification of the ER expression by dietary factors in the human colon is entirely plausible, and should be considered both as a mechanism with the potential to affect vulnerability to disease and in relation to the effectiveness of drug treatment. These studies show, for the first time, physiological effects of the two different dietary components that are frequently consumed together in certain cuisines, at two different sites where long-term exposure might modify cancer risk. We have also successfully applied a method of measuring mitosis and apoptosis well established for intestinal crypts to the TEB of the mammary gland. Fish oil and isoflavonoid-enriched proteins modify both cell proliferation rate and gene expression of ER $\alpha$ and $E R \beta$ in both the colon and the mammary gland in a tissue- and dietspecific manner. However, only fish oil increases apoptosis, a potentially beneficial effect found in both the colon and the mammary gland. Thus, fish oil leads to the changes that could be interpreted as generally protective in both tissues, while, for isoflavonoids, the data support the previous studies, suggesting a possible cause for concern over the consumption of soya protein post-puberty and with respect to breast cancer treatment.

\section{Acknowledgements}

F. K. was funded by a European Union Marie Curie Fellowship under the guidance of and with the assistance from E. K. L. and J. F. D., F. K. and E. K. L. carried out all the data analysis while I. T. J. acted in an advisory role. All authors were involved in the writing of the manuscript. There are no conflicts of interest in relation to the present paper.

\section{References}

1. Lechner D, Kallay E \& Cross HS (2005) Phytoestrogens and colorectal cancer prevention. Vitam Horm 70, 169-198.

2. Qin LQ, Xu JY, Wang PY, et al. (2006) Soyfood intake in the prevention of breast cancer risk in women: a meta-analysis of observational epidemiological studies. J Nutr Sci Vitaminol $\mathbf{5 2}, 428-436$.

3. Xiao CW, Mei J, Huang W, et al. (2007) Dietary soy protein isolate modifies hepatic retinoic acid receptor-beta proteins and inhibits their DNA binding activity in rats. $J$ Nutr 137, 1-6.

4. Breinholt V, Hossaini A, Svendsen GW, et al. (2000) Estrogenic activity of flavonoids in mice. The importance of estrogen receptor distribution, metabolism and bioavailability. Food Chem Toxicol 38, 555-564.

5. Casanova M, You L, Gaido KW, et al. (1999) Developmental effects of dietary phytoestrogens in Sprague-Dawley rats and interactions of genistein and daidzein with rat estrogen receptors alpha and beta in vitro. Toxicol Sci 51, 236-244.

6. Santell RC, Chang YC, Nair MG, et al. (1997) Dietary genistein exerts estrogenic effects upon the uterus, mammary gland and the hypothalamic/pituitary axis in rats. $J$ Nutr 127, 263-269.

7. Kuiper GG, Lemmen JG, Carlsson B, et al. (1998) Interaction of estrogenic chemicals and phytoestrogens with estrogen receptor beta. Endocrinology 139, 4252-4263.
8. Jacobs MN, Dickins M \& Lewis DF (2003) Homology modelling of the nuclear receptors: human oestrogen receptorbeta (hERbeta), the human pregnane-X-receptor (PXR), the Ah receptor (AhR) and the constitutive androstane receptor (CAR) ligand binding domains from the human oestrogen receptor alpha (hERalpha) crystal structure, and the human peroxisome proliferator activated receptor alpha (PPARalpha) ligand binding domain from the human PPARgamma crystal structure. J Steroid Biochem Mol Biol 84, 117-132.

9. Kumar N, Allen K, Riccardi D, et al. (2004) Isoflavones in breast cancer chemoprevention: where do we go from here? Front Biosci 9, 2927-2934.

10. Ochiai M, Watanabe M, Kushida H, et al. (1996) DNA adduct formation, cell proliferation and aberrant crypt focus formation induced by $\mathrm{PhIP}$ in male and female rat colon with relevance to carcinogenesis. Carcinogenesis 17, 95-98.

11. Farquhar CM, Marjoribanks J, Lethaby A, et al. (2005) Long term hormone therapy for perimenopausal and postmenopausal women. The Cochrane Database of Systematic Reviews 2005, issue 3, CD004143. http//www.mrw.interscience.wiley.com/ cochrane/clsyrev/articles/CD004143/frame.html.

12. Mueller SO, Clark JA, Myers PH, et al. (2002) Mammary gland development in adult mice requires epithelial and stromal estrogen receptor alpha. Endocrinology 143, 2357-2365.

13. Roger P, Sahla ME, Makela S, et al. (2001) Decreased expression of estrogen receptor beta protein in proliferative preinvasive mammary tumors. Cancer Res 61, 2537-2541.

14. Zhao C, Lam EW, Sunters A, et al. (2003) Expression of estrogen receptor beta isoforms in normal breast epithelial cells and breast cancer: regulation by methylation. Oncogene $\mathbf{2 2}$, 7600-7606.

15. Campbell-Thompson M, Lynch IJ \& Bhardwaj B (2001) Expression of estrogen receptor (ER) subtypes and ERbeta isoforms in colon cancer. Cancer Res 61, 632-640.

16. Foley EF, Jazaeri AA, Shupnik MA, et al. (2000) Selective loss of estrogen receptor beta in malignant human colon. Cancer Res 60, 245-248.

17. Slattery ML, Sweeney C, Murtaugh M, et al. (2005) Associations between ERalpha, ERbeta, and AR genotypes and colon and rectal cancer. Cancer Epidemiol Biomarkers Prev 14, 2936-2942.

18. Norat T, Bingham S, Ferrari P, et al. (2005) Meat, fish, and colorectal cancer risk: the European prospective investigation into cancer and nutrition. J Natl Cancer Inst 97, 906-916.

19. Calder PC, Davis J, Yaqoob P, et al. (1998) Dietary fish oil suppresses human colon tumour growth in athymic mice. Clin Sci (Colch) 94, 303-311.

20. Paulsen JE, Elvsaas IK, Steffensen IL, et al. (1997) A fish oil derived concentrate enriched in eicosapentaenoic and docosahexaenoic acid as ethyl ester suppresses the formation and growth of intestinal polyps in the Min mouse. Carcinogenesis 18, 1905-1910.

21. Reddy BS, Burill C \& Rigotty J (1991) Effect of diets high in omega-3 and omega- 6 fatty acids on initiation and postinitiation stages of colon carcinogenesis. Cancer Res 51, 487-491.

22. Anti M, Armelao F, Marra G, et al. (1994) Effects of different doses of fish oil on rectal cell proliferation in patients with sporadic colonic adenomas [see comments]. Gastroenterology 107, 1709-1718.

23. Cheng JL, Ogawa K, Kuriki K, et al. (2004) Increased intake of $n-3$ polyunsaturated fatty acids elevates the level of apoptosis in the normal sigmoid colon of patients polypectomized for adenomas/tumors (193, 17, 2003). Cancer Lett 205, 227.

24. Lund E (2006) Dietary fatty acids and colon cancer. Scand $J$ Food Nutr 50, 39-44.

25. Nixon JB, Kamitani H, Baek SJ, et al. (2003) Evaluation of eicosanoids and NSAIDs as PPARgamma ligands in colorectal 
carcinoma cells. Prostaglandins Leukot Essent Fatty Acids 68 323-330.

26. Latham P, Lund EK \& Johnson IT (1999) Dietary n-3 PUFA increases the apoptotic response to 1,2-dimethylhydrazine, reduces mitosis and suppresses the induction of carcinogenesis in the rat colon. Carcinogenesis 20, 645-650.

27. Latham P, Lund EK, Brown JC, et al. (2001) Effects of cellular redox balance on induction of apoptosis by eicosapentaenoic acid in HT29 colorectal adenocarcinoma cells and rat colon in vivo. Gut 49, 97-105.

28. Caygill CP \& Hill MJ (1995) Fish, $n$-3 fatty acids and human colorectal and breast cancer mortality. Eur J Cancer Prev 4, 329-332.

29. Engeset D, Alsaker E, Lund E, et al. (2006) Fish consumption and breast cancer risk. The European prospective investigation into cancer and nutrition (EPIC). Int J Cancer 119, 175-182.

30. Kaizer L, Boyd NF, Kriukov V, et al. (1989) Fish consumption and breast cancer risk: an ecological study. Nutr Cancer 12, 61-68.

31. Gago-Dominguez M, Yuan JM, Sun CL, et al. (2003) Opposing effects of dietary $n-3$ and $n-6$ fatty acids on mammary carcinogenesis: the Singapore Chinese Health Study. Br J Cancer 89, 1686-1692.

32. Karmali RA, Donner A, Gobel S, et al. (1989) Effect of $n-3$ and n-6 fatty acids on 7,12-dimethylbenz (a) anthracene-induced mammary tumorigenesis. Anticancer Res 9, 1161-1167.

33. Sasaki T, Kobayashi Y, Shimizu J, et al. (1998) Effects of dietary $n-3$-to- $n-6$ polyunsaturated fatty acid ratio on mammary carcinogenesis in rats. Nutr Cancer 30, 137-143.

34. Karmali RA, Marsh J \& Fuchs C (1984) Effect of omega-3 fatty acids on growth of a rat mammary tumor. J Natl Cancer Inst $\mathbf{7 3}$, 457-461.

35. Kramer F, Jensen PS, Vinggaard AM, et al. (2003) Effect of in utero-administered coumestrol, equol, and organic selenium on biomarkers for phase 2 enzyme capacity and redox status. Nutr Cancer 46, 73-81.

36. Bustin SA (2002) Quantification of mRNA using real-time reverse transcription PCR (RT-PCR): trends and problems. $J$ Mol Endocrinol 29, 23-39.

37. Hall JM \& McDonnell DP (1999) The estrogen receptor betaisoform (ERbeta) of the human estrogen receptor modulates ERalpha transcriptional activity and is a key regulator of the cellular response to estrogens and antiestrogens. Endocrinology 140, 5566-5578.

38. Zhang J, Svehlikova V, Bao Y, et al. (2003) Synergy between sulforaphane and selenium in the induction of thioredoxin reductase 1 requires both transcriptional and translational modulation. Carcinogenesis 24, 497-503.

39. Smith RA, Lea RA, Weinstein SR, et al. (2006) Detection of mRNA levels for the estrogen alpha, estrogen beta and androgen nuclear receptor genes in archival breast cancer tissue. Cancer Lett 237, 248-255.

40. Pell JD, Brown JC \& Johnson IT (1994) Polyunsaturated fatty acids of the $n-3$ series influence intestinal crypt cell production in rats. Carcinogenesis 15, 1115-1119.

41. Chang WL, Chapkin RS \& Lupton JR (1998) Fish oil blocks azoxymethane-induced rat colon tumorigenesis by increasing cell differentiation and apoptosis rather than decreasing cell proliferation. J Nutr 128, 491-497.

42. Hoff MB \& Chang WW (1979) The effect of estrogen on epithelial cell proliferation and differentiation in the crypts of the descending colon of the mouse: a radioautographic study. Am J Anat 155, 507-516.

43. Wada-Hiraike O, Imamov O, Hiraike H, et al. (2006) Role of estrogen receptor beta in colonic epithelium. Proc Natl Acad Sci U S A 103, 2959-2964.

44. Hsu HH, Cheng SF, Wu CC, et al. (2006) Apoptotic effects of over-expressed estrogen receptor-beta on LoVo colon cancer cell is mediated by p53 signalings in a ligand-dependent manner. Chin J Physiol 49, 110-116.

45. Enmark E, Pelto-Huikko M, Grandien K, et al. (1997) Human estrogen receptor beta-gene structure, chromosomal localization, and expression pattern. J Clin Endocrinol Metab 82, $4258-4265$.

46. Singh S, Poulsom R, Hanby AM, et al. (1998) Expression of oestrogen receptor and oestrogen-inducible genes pS2 and ERD5 in large bowel mucosa and cancer. J Pathol 184, 153-160.

47. Bises G, Bajna E, Manhardt T, et al. (2007) Gender-specific modulation of markers for premalignancy by nutritional soy and calcium in the mouse colon. $J$ Nutr 137, 211S-215S.

48. Saji S, Sakaguchi H, Andersson S, et al. (2001) Quantitative analysis of estrogen receptor proteins in rat mammary gland. Endocrinology 142, 3177-3186.

49. Russo IH \& Russo J (1996) Mammary gland neoplasia in longterm rodent studies. Environ Health Perspect 104, 938-967.

50. Le Marchand L, Haiman CA, Wilkens LR, et al. (2004) MTHFR polymorphisms, diet, HRT, and breast cancer risk: the multiethnic cohort study. Cancer Epidemiol Biomarkers Prev 13, 2071-2077.

51. Cappelletti V, Miodini P, Di Fronzo G, et al. (2006) Modulation of estrogen receptor-beta isoforms by phytoestrogens in breast cancer cells. Int J Oncol 28, 1185-1191.

52. Diel P, Olff S, Schmidt S, et al. (2001) Molecular identification of potential selective estrogen receptor modulator (SERM) like properties of phytoestrogens in the human breast cancer cell line MCF-7. Planta Med 67, 510-514.

53. Fan YY, Spencer TE, Wang N, et al. (2003) Chemopreventive $n-3$ fatty acids activate $\mathrm{RXR} \alpha$ in colonocytes. Carcinogenesis.

54. Faddy HM, Robinson JA, Lee WJ, et al. (2006) Peroxisome proliferator-activated receptor alpha expression is regulated by estrogen receptor alpha and modulates the response of MCF-7 cells to sodium butyrate. Int J Biochem Cell Biol 38, 255-266.

55. Stoll BA (2002) Linkage between retinoid and fatty acid receptors: implications for breast cancer prevention. Eur J Cancer Prev 11, 319-325.

56. Maggiolini M, Bonofiglio D, Marsico S, et al. (2001) Estrogen receptor alpha mediates the proliferative but not the cytotoxic dose-dependent effects of two major phytoestrogens on human breast cancer cells. Mol Pharmacol 60, 595-602.

57. Dave B, Eason RR, Till SR, et al. (2005) The soy isoflavone genistein promotes apoptosis in mammary epithelial cells by inducing the tumor suppressor PTEN. Carcinogenesis 26, $1793-1803$.

58. Alferez D \& Goodlad RA (2007) To best measure cell proliferation in samples from the intestine. Cell Prolif 40, 231-240.

59. DeGraffenried LA, Friedrichs WE, Fulcher L, et al. (2003) Eicosapentaenoic acid restores tamoxifen sensitivity in breast cancer cells with high Akt activity. Ann Oncol 14, 1051-1056.

60. Umekita Y, Souda M, Ohi Y, et al. (2006) Expression of wildtype estrogen receptor beta protein in human breast cancer: specific correlation with HER2/neu overexpression. Pathol Int 56, 423-427.

61. Berrino F, Bellati C, Secreto G, et al. (2001) Reducing bioavailable sex hormones through a comprehensive change in diet: the diet and androgens (DIANA) randomized trial. Cancer Epidemiol Biomarkers Prev 10, 25-33.

62. Xiao CW, Wood C \& Gilani GS (2006) Nuclear receptors: potential biomarkers for assessing physiological functions of soy proteins and phytoestrogens. J AOAC Int 89, $1207-1214$

63. Garreau JR, Muller P, Pommier R, et al. (2006) Transgenic introduction of androgen receptor into estrogen-receptor-, progesterone-receptor-, and androgen-receptor-negative breast cancer cells renders them responsive to hormonal manipulation. Am J Surg 191, 576-580. 